\title{
City-Level Audit Economies of Scale and Audit Fees
}

\author{
Xiaping Ye \\ Management School, Jinan University, Guangzhou, China \\ Email: 563589756@qq.com
}

How to cite this paper: Ye, X.P. (2016) City-Level Audit Economies of Scale and Audit Fees. Modern Economy, 7, 13311337.

http://dx.doi.org/10.4236/me.2016.711125

Received: May 19, 2016

Accepted: October 24, 2016

Published: October 27, 2016

Copyright (@) 2016 by author and Scientific Research Publishing Inc. This work is licensed under the Creative Commons Attribution International License (CC BY 4.0).

http://creativecommons.org/licenses/by/4.0/

\begin{abstract}
All dates are from China companies between 2010 and 2014. From the aspect of the urban area level, the article explains the influence of the geographical positions of the accounting firms and client company and the size of the accounting firm on audit fees. There is a significant correlation between the fees and the distance. The results suggest that geography is significant and positively affects audit fees if audit firm and client company are in the same area; at the same time, audit firms' scale economies can reduce audit fees for the study based on city-level (if audit firm and the client company are in the same area). Specially, audit location affects audit fees more significantly when audit firm has scale economy. These results suggest that geography and economies of scale affect audit fees.
\end{abstract}

\section{Keywords}

City-Level, Economies of Scale, Audit Fees

\section{Introduction}

In China, audit market is inadequacy, and recently, many scholars have taken various methods to study basic audit theories to develop the audit market, and tried their best to prove that their findings are reliable. Over the last few years, some scholars have studied the geographical characteristics between audit firm and customer company; they believed the distance was one of the important factors which affected audit fees and audit quality. But most of them focused on the relation between corporate governance and audit fees or quality (such as Wangfeng Zhang (2011) [1], Yuedong Li (2014) [2], etc.), audit firms merger (Yamin Ceng (2012) [3], Minghui Li (2012) [4], etc.), audit risk (Keqin Pan (2008) [5], Yanheng Song (2011) [6], etc.); only few scholars checked the influence from outside such as geographical characteristic. Wenjun Liu (2014) [7] 
showed that the audit fees from further firm were significantly lower than nearer one by calculating latitude and longitude, and proved this result in an empirical and powerful way. The place where customers are located has an influence on the money paid in the end. But only few researchers focused on the way that geography factors affected the auditor's final judgment in this field.

Based on the researches of Fung, Gul and Krishnan (2012) [8], the varieties of scale economy are determined by the company's total income and ranking. The article examines the relation between scale economy and audit fees. Besides, it also shows the relation between geography factor (city-level) and audit fees, and then puts forward the research hypotheses. The research conclusions have supplementary meaning for audit pricing determining. It also expands the theory of Wenjun Lin (2014) [7] about the auditor geographical position and audit pricing, and indicates that customers should not only care about firms' location but also focus on cities' development.

\section{Literature Review and Hypothesis Development}

In China, study on auditor location and audit pricing is still in an initial stage, and only few researches focus on it; however, literatures abroad concentrate more on the auditor location and audit quality, for example, Knechel et al. (2007) [9] examined the correlation between auditor location and audit quality on the basis of business information, and found that location was important for audit firms to collect audit company' information, in addition to gathering information by manager, and proving large information which will lead to higher audit quality. De Fond et al. (2011) [10] found "non-big four" away from the SEC Regional more likely to give continuous audit opinions when they faced financial distress company, and indicated the location affected audit opinion. Choi et al. (2012) [11] found audit quality may be much higher if they were audited by native audit firms, however, non-native audit firms perform oppositely. Chen et al (2010) [12], Chhaochaharia et al. (2012) [13] and Durendez Gomez (2012) [14] examined the geographical characteristics between audit firms and companies; they also believe location is an important factor for in determining price

Researches on audit market of China are developing. Some researchers such as Mei Zhang (2011) [15] found local audit firms are easy to get finance information compared to non-local audit firms. Therefore, the local audit firms tend to give higher audit quality, because they can get more information about the company. It will be more likely to make audit plan, collect audit evidence effectively, and avoid audit risk, then the audit quality will be more higher; Yilin Wang, Guilian Wang (2014) [16] found a positive correlation between audit location and audit quality after modifying the model of Jones. Although most scholars concentrate on the relation between location and audit quality, Wenjun Lin (2014 [7] found the distance was a key factor which infects audit fees by using Google map. The audit fees significantly decrease due to a lack of advantages in geographical distance especially when they are too far from each other, which indicate the auditor's location affects the bargaining power and pricing strategy. Wenjun Lin (2014) [7] also found audit fees were infected by product market competition in differ- 
ent cities. Therefore, the hypothesis 1 is put forward.

$\mathrm{H}$ 1: If the audit firm and the company are in the same city, audit firm will charge higher audit fees.

With the economy developing, audit firm's business volume is rising. At the same time, firms merge is increasing, and audit firm's scale is expanding. Benefiting from scale expansion, audit firms can share audit cost with more customers, reducing the unit audit cost and leading to internal economies of scale. Hong Lin Han, Hanwen Chen (2008) [17] found audit firms classified the potential target customers according to the scales of customers. The audit firms which have multiplied but small size clients adopt a leadership strategy due to economy of scale. Moreover, because of the fierce competition, audit firms may use different resources in different regions according to different investment projects such as in first-tier cities. It may increase the audit cost and infect audit pricing because excellent and talented market needs high cost. Hongqi Yuan, Weifang Han (2012) [18] found market competition had an effect on the audit quality. Furthermore, earning manipulation gets lower and audit quality are higher in fierce competition market. In addition, industry scale expansion is an effective way to improve audit firm's competition. Therefore, the hypothesis 2 was put forward.

H 2: if audit firm and company are in the same city, audit location infects audit fees more significantly when audit firm has scale economy.

\section{Research Design}

\subsection{Sample and Data}

All dates are taken from Chinese listed companies from 2010 to 2014. At the same time, the article excludes financial sector and ST shares, deletes the firms' dates which only have one firm in one industry and all missing dates. All dates are collected from CSMAR database. It should be noted that the article constructs variable scale economy by measuring audit firms' total income Percentile Ranking, and it mainly consider Provincial Administration characters of China (Xi Wu and Junsheng Zhang, 2012) [19].

\subsection{Construction of the Model}

The purpose of constructing variable scale economy is to test the motivation of geography infecting audit fees, so the interaction variable of a scale economy and city-level is necessary. At the same time scale economy variety is related to "regional dimension", which is contributed to by the audit firms' city. In order to control industries and years, the article set industrial and variable dummy. The research model is as the followed:

$$
\begin{aligned}
\mathrm{LAF}= & \alpha_{0}+\alpha_{1} \text { CityL }+\alpha_{2} \text { Scale }+\alpha_{3} \text { CityL } \times \text { Scale }+\alpha_{4} \text { size } \\
& +\alpha_{5} \text { cata }+\alpha_{6} \text { quick }+\alpha_{7} \text { lev }+\alpha_{8} \text { roi }+\alpha_{9} \text { growth } \\
& +\alpha_{10} \text { loss }+\alpha_{11} \text { op }+\sum \text { Year }+\sum \text { Industry }+\varepsilon
\end{aligned}
$$

\subsection{Variable Description}

The dependent variable is natural logarithm of audit fees. City L equals to 1 if audit firm 
and company in the same city, and it's represent geographical variable. The article use audit firm' total income percentile ranking as Scale, it refers to audit firm' economics of scale. Except that the article also set cross term to examine how does audit pricing change when audit firm and company in the same city and audit firm have scale economy.

The main purpose of others independent variables is to control same factors which may infect regression results, for instance, the article will discuss the hypotheses in the same size condition if control company size. Other control variables like shot-term liquidity, liquidity solvency, Operational capability, Profitability, Growth capacity, Lasting capacity, Audit opinion are also service for model's independence, and they are all description in Table 1 . The article also control year and industry factor.

\subsection{Descriptive Statistic}

Table 2 shows descriptive statistics in all main variables. The average of LAF is equal to 13.55 million and median is equal to 13.43 million, standard deviation is equal to 0.73456. All LAF dates it showed are availability. City L (if audit firm and company are in the same city) is dummy variable; the average is equal to 0.106678 , which shows that most of the audit firms and companies are far away from each other. Scale economy variables are based on percentile ranking of audit firm's total income. That the average is equal to 36.1872 shows audit firms' clients are relatively concentrated, but that standard deviation is equal to 42.49472 shows big audit firms have lots of big clients, and small ones only have few in fact. Short-term Liquidity average is equal to 0.57248 , median is

Table 1. Variables description.

\begin{tabular}{|c|c|c|c|}
\hline Variable Type & Variable Measure & Variable Sign & Variable Interpretation \\
\hline \multirow[t]{2}{*}{ Dependent variable } & Audit fees & LAF & Natural logarithm of audit fee \\
\hline & City-level & City L & $\begin{array}{l}\text { City } L=1 \text { if audit firm and } \\
\text { company in a same city }\end{array}$ \\
\hline \multirow[t]{7}{*}{ Independent variable } & Economic scale & Scale & $\begin{array}{l}\text { Total income Percentile Ranking } \\
\text { based on regional -level }\end{array}$ \\
\hline & Cross terms & City $\mathrm{L} \times$ Scale & \\
\hline & Company size & Size & Natural logarithm of total asset \\
\hline & Short-term Liquidity & Cata & Current assets/current liabilities \\
\hline & Liquidity solvency & Quick & Quick assets/current liabilities \\
\hline & Operational capability & LEV & Total liabilities/total assets \\
\hline & Profitability capability & ROI & Pre-tax income/total assets \\
\hline \multirow{5}{*}{ Control variable } & Growth capacity & Growth & Growth rate of operating income \\
\hline & Lasting capacity & Loss & Loss $=1$ if Net profit less than 0 ,or loss $=0$ \\
\hline & Audit opinion & Op & $\begin{array}{l}\text { Op }=1 \text { if give Standard } \\
\text { without reservation, or op }=0\end{array}$ \\
\hline & Regression year & Year & Fixed variable \\
\hline & Regression industry & Industry & Fixed variable \\
\hline
\end{tabular}


Table 2. Descriptive statistics.

\begin{tabular}{ccccccc}
\hline Variable & Date & Min & Max & Mean & Median & Standard Deviation \\
\hline LAF & 10,227 & 9.21034 & 18.11958 & 13.54817 & 13.42985 & 0.73456 \\
City L & 10,227 & 0 & 1 & 0.106678 & 0 & 0.30872 \\
A cale & 10,227 & 1 & 100 & 36.18725 & 34.13876 & 42.49472 \\
City L $\times$ Scale & 10,227 & 0 & 100 & 7.066002 & 0 & 22.67804 \\
Size & 10,227 & 16.11671 & 28.50873 & 21.91484 & 21.75908 & 1.33142 \\
Cata & 10,227 & 0.00868 & 1 & 0.57248 & 0.59024 & 0.21699 \\
Quick & 10,227 & -5.13164 & 204.7421 & 2.72389 & 1.55504 & 5.32821 \\
LEV & 10,227 & -0.19469 & 29.49299 & 0.45338 & 0.43265 & 0.49397 \\
ROI & 10,227 & -6.77223 & 108.3657 & 0.065044 & 0.04404 & 1.11216 \\
Growth & 10,227 & -0.99971 & 134607.1 & 15.19083 & 0.121949 & 1339.184 \\
Loss & 10,227 & 0 & 1 & 0.08233 & 0 & 0.27488 \\
Op & 10,227 & 0 & 1 & & 1 & 0.18698
\end{tabular}

equal to 0.59024 and standard deviation is 0.21699 , which indicate that the Short-term Liquidity perform in a perfect condition. The average velocity ratio is equal to 0.57248 , and the median is equal to 1.55504 , standard deviation is equal to 5.32821 , and there is a big difference between maximum and minimum. The average and median show a normal Liquid solvency. LEV average is equal to 0.45338 , and the median is equal to 0.43265 , which indicate total debt level is moderate. ROI average is equal to 0.06504 , and the median is equal to 0.04404 , and Loss average is equal to 0.08233 , which indicate the company profitability is low. The average of audit types is equal to 0.96372 , which indicate $96.37 \%$ companies belong to standard unqualified audit opinion.

\subsection{Results}

The regression result is shown in Table 3, the City $\mathrm{L}$ regression coefficient is equal to 0.16 , and significantly position in $1 \%(t=7.14)$ after controlling others factors, which indicates audit firms charge more audit fees when providing audit services in the same city, hypothesis 1 is established.

The Scale variable regression coefficient is equal to 0.0015 , and significant negative in $1 \%(t=-10.78)$, so the result shows audit firms reduce audit fees in case of scale economy. Cross term Regression coefficient is 0.0038 , and significant positive in $1 \%(\mathrm{t}$ $=10.25$ ), both of them indicate if audit firm and company are in the same city, the power of audit location on audit fees are more stronger when audit firms have scale economy. Therefore, Assumption 2 is established. The result of $\mathrm{Adj}-R^{2}$ indicates the regression model is perfect; all independent variables are with a powerful description.

The conclusion that audit fees are influenced a lot by where the audit firms are located is drawn after comparing city level, and testing the relation between audit firms' scale economy and audit fees. The regressive result explained more nearer both are, 
Table 3. Regression result.

\begin{tabular}{ccc}
\hline Independent Variable & LAF & Regression Result \\
\hline Main variable & CityL & $0.15559041^{* * *}$ \\
& Scale & $-0.00147448^{* * *}$ \\
& City L $\times$ Scale & $0.00375065^{* * *}$ \\
& Size & $0.42579368^{* * *}$ \\
Control variable & Cata & $-0.0441803^{* *}$ \\
& Quick & $-0.00293035^{* * *}$ \\
& LEV & $0.0532918^{* * *}$ \\
& ROI & $0.01811415^{* * *}$ \\
& Growth & $-3.107 \mathrm{e}-06^{* * *}$ \\
& Loss & $0.06244252^{* * *}$ \\
Fixed variable & Op & $-0.23961865^{* * *}$ \\
& Year & Yes \\
& Industry & Yes \\
& N & 10,227 \\
& Adj $-R^{2}$ & 0.42 \\
& F & 129.7 \\
\hline
\end{tabular}

more fees should be paid, apart from the situation where audit firms are likely to make lower pricing strategy when audit firms have scale economy.

\section{Conclusion}

It can be concluded as follows: First, it is the distance between customers and audit firms that has a big impact on fees needed, which can encourage many audit firms to establish lots of branches in the places where customers focus, like Peking and Shanghai. Secondly, scale economy is one of the important reasons why audit fees decrease, besides, scale economy and audit service in the same city also have a synergistic effect on determining the final audit price. The results provide a further recognition in checking the relation among scale economy, geography and audit fees. Such audit firms benefit a lot from location advantage. And a familiar city is crucial for audit firms to provide audit services. In brief, the conclusions of this article play an important role in audit market researches.

\section{References}

[1] Zhang, W.F., Zhang, Z.G. and Yang, Q.X. (2011) Internal Control and Audit Pricing Evidence from China. Audit Research, 5, 65-72.

[2] Li, Y.D., Zhang, D. and Liu, W.W. (2014) Internal Control Defects, Property and Audit Pricing. Audit Research, 2, 45-52.

[3] Zeng, Y.M., Zhang, J.S. (2012) Accounting Firm Merger, Audit Market Structure and Audit 
Pricing. Audit \& Economic Research, 1, 40-47.

[4] Li, M.H., Zhang, J. and Zhang, X.X. (2012) Accounting firm Merger and Audit Pricing-Based on Ten Accounting Firm Merger Dates in 2003-2009. Accounting Research, 5, 86-92, 94 .

[5] Pan, K.Q. (2012) Corporate Governance, Audit Risk and Audit Pricing Evidence from CCGI-(NK). Nankai Business Review, 1, 106-112.

[6] Song, Y.H. (2011) Audit Risk, Audit Pricing and Relative Bargaining Power Evidence from Punishment or Investigation Company by the Regulatory Authorities. Accounting Research, 2, 79-84, 97.

[7] Liu, W.J. (2014) The Location of Auditor and Audit Pricing Strategy. Finance Research, 9, 121-132.

[8] Fung, S.Y.K., Gul, F.A. and Krishnan, J. (2012) City-Level Auditor Industry Specialization, Economies of Scale, and Audit Pricing. The Accounting Review, 87, 1281-1307. http://dx.doi.org/10.2308/accr-10275

[9] Knechel, W. and Vanstraelen, A. (2007) The Relationship between Auditor Tenure and Audit Quality Implied by Going Concern Opinions. Auditing. A Journal of Practice \& Theory, 26, 113-131. http://dx.doi.org/10.2308/aud.2007.26.1.113

[10] DeFond, M. and Lennox, C. (2011) The Effect of SOX on Small Auditor Exits and Audit Quality. Journal of Accounting \& Economics, 52, 21-40. http://dx.doi.org/10.1016/j.jacceco.2011.03.002

[11] Choi, J., Kim, J., Qiu, A. and Zang, Y. (2012) Geographic Proximity between Auditor and Client: How Does It Impact Audit Quality? Journal of Practice \& Theory, 31, 43-72.

[12] Chen, S., Sun, S.Y.J. and Wu. D.H. (2010) Client Importance, Institutional Improvements, and Audit Quality in China: An Office and Individual Auditor Level Analysis. The Accounting Review, 85, 127-158. http://dx.doi.org/10.2308/accr.2010.85.1.127

[13] Chhaochharia, V., Kumar, A. and Niessen-Ruenzi, A. (2012) Local Investors and Corporate Governance. Journal of Accounting and Economics, 54, 42-67. http://dx.doi.org/10.1016/j.jacceco.2012.03.002

[14] Gómez-Guillamón, A.L.D. (2012) The Geographical Factor in the Determination of Audit Quality. Spanish Accounting Review, 15, 287-310.

[15] Zhang, M. (2011) The Region of Auditor and Audit Quality: Information or Conflict? -Evidence from China. Accounting Society of China Financial Cost Branch.

[16] Wang, Y.L. and Wang, G.L. (2014) How Does Geographical Effect Audit Quality. China $C P A, 10,80-84$.

[17] Han, H.L. and Chen, H.W. (2008) Industry Specialization Is an Effective Competitive Strategy?-Evidence from China. Audit Research, 3, 275-302.

[18] Yuan, Y.Q. and Han, W.F. (2012) CPA Characteristics and Audit Quality. China Accounting Review, 1, 53-60.

[19] Wu, X. and Zhang, J.S. (2012) The Local Audit Firm Market Status and Economy Return. Accounting Research, 7, 80-88, 97. 
Submit or recommend next manuscript to SCIRP and we will provide best service for you:

Accepting pre-submission inquiries through Email, Facebook, LinkedIn, Twitter, etc. A wide selection of journals (inclusive of 9 subjects, more than 200 journals)

Providing 24-hour high-quality service

User-friendly online submission system

Fair and swift peer-review system

Efficient typesetting and proofreading procedure

Display of the result of downloads and visits, as well as the number of cited articles

Maximum dissemination of your research work

Submit your manuscript at: http://papersubmission.scirp.org/

Or contact me@scirp.org 